OPEN ACCESS

ISSN 2548-3501 (online)

Edited by: Eny Maryanti

Reviewed by: Fityan Izza N.

${ }^{*}$ Correspondence:

Fajrin Noho

fajrinnnohoo27@gmail.com Received: 15 Desember 2021 Accepted: 12 January 2021

Published: 31 January 2021

Citation:

Noho (2021) Senioritas Auditor,

Pengalaman Auditor Dan

Keahlian Auditor Terhadap

Profesional Judgment Dengan

Locus of Control Sebagai

Variabel Moderasi

\section{Senioritas Auditor, Pengalaman Auditor dan Keahlian Auditor terhadap Profesional Judgment fengan Locus of Control sebagai Variabel Moderasi}

\section{Auditor Seniority, Auditor Experience and Auditor Expertise on Professional Judgment with Locus of Control as Moderating Variable}

\author{
Fajrin Noho *, Sabaruddin, Sulhendri \\ Fakultas Ekonomi dan Bisnis, Universitas Muhammadiyah Jakarta, Indonesia
}

This study aims to see "The influence of senior auditors, auditor experience, and expertise of professional judgments with Locus of Control as a Moderation Variable (Empirical Study of Public Accounting Firms in Jakarta). The research method is included in quantitative research with primary data types. The population in this study is a public accounting firm in the Jakarta area and the sample in this study are auditors who work in public accounting firms in the Jakarta area. The number of samples in this study were 150 auditors. Data analysis in this study using data analysis method WarpPLS (Partial Least Square) Version 7.0. Based on the research and test results, it shows that the auditor seniority variable has no effect on professional judgment, while the auditor experience and expertise variables have an effect on professional judgment. Furthermore, Locus of Control is unable to moderate the effect of auditor seniority, auditor experience, auditor expertise on professional judgment.

Keywords: Senior Auditors, Auditor Experience, Auditor Expertise, Professional Assessment

Penelitian ini bertujuan untuk mengetahui pengaruh senioritas auditor, pengalaman auditor, keahlian auditor terhadap professional judgment dengan locus of control sebagai variable moderasi. Metode penelitian ini termasuk penelitian kuantitatif dengan jenis sumber data primer. Populasi dalam penelitian ini adalah kantor akuntan public di wilayah dki Jakarta dan sampel dalam penelitian ini adalah auditor yang bekerja di kantor akutan public di dki Jakarta. Jumlah sampel yang dalam penelitian ini adalah sebanyak 150 auditor. Analisis data dalam penelitian ini menggunakan metode analisis data WarpPLS (Partial Least Square) versi 7.0. berdasarkan hasil penelitian dan hasil pengujian hipotesis menunjukkan bahwa variable senioritas auditor tidak berpengaruh terhadap professional judgment. Sedangkan variabel pengalaman auditor dan keahlian auditor berpengaruh terhadap professional judgment. Selanjutnya locus of control tidak mampu memoderasi pengaruh senioritas auditor, pengalaman auditor keahlian auditor terhadap professional judgment.

Keywords: Senioritas auditor,Pengalaman auditor,Keahlian auditor, Profesional judgment 


\section{PENDAHULUAN}

Jasa akuntan publik merupakan jasa yang digunakan baik itu investor, kreditor, dan pihak lain yang terkait untuk menilai perusahaan atau badan hukum lainnya (termasuk pemerintah) untuk menghasilkan pendapat atau opini tentang laporan keuangan yang relevan, akurat, lengkap, dan disajikan secara wajar (Maharani, 2014). akuntan mempunyai peran penting dalam memberikan informasi keuangan yang handal bagi semua pihak yang berkepentingan. Keberhasilan auditor sangat diperlukan dalam audit judgment yang berkualitas. Menurut Komalasari dan Hernawati (2015) Audit judgment merupakan kebutuhan auditor untuk mengaudit laporan keuangan perusahaan dan mengembangkan bukti yang diperoleh secara jelas berdasarkan kemampuan yang dimiliki auditor, untuk menghasilkan ketetapan kualitas opini audit yang dikeluarkan oleh auditor.

Dalam standar profesi akuntan publik seorang auditor diharuskan mengunakan pertimbangan profesionalnya dalam memberikan penilain mengenai dengan audit. Auditor harus melakukan kerja keras untuk memberikan pendapat dengan judgment yang logis agar tidak muncul keraguan dalam aktifitas perusahaan (Seldivianiggar, 2018). Oleh karena itu, Seorang auditor harus hati-hati dalam menentukan judgment agar tidak terjadi seperti pada kasus pada PT SNP Finance yang terkena skandal pemalsuan laporan keuangan tiba-tiba mengalami defaut atau gagal bayar atas kewajibannya kepada sejumlah krediturnya, fraud ini terjadi pada tahun 2018 setelah pihak berwenang mengungkapkan dugaan transkasi nakal PT SNP Finance anak usaha jaringan ritel Colombia. Kualitas dari audit judgment ini akan menunjukkan seberapa baik kinerja seorang auditor dalam melakukan tugasnya. Salah satu faktor yang mempengaruhi audit judgment adalah Senioritas auditor. Senioritas auditor memberikan gambaran tengtang pengalaman auditor. Semakin lama auditor bekerja maka semakin banyak pula pengalaman yang dimiliki oleh seorang auditor Semakin lama auditor bekerja maka semakin banyak pula pengalaman yang dimiliki oleh seorang auditor. Hasil penelitian Agustini dan Merkusiwati (2016) Irlianti (2019) mengatakan bahwa senioritas auditor tidak berpengaruh signifikan terhadap audit judgment. Sedangkan Pratiwi (2017) mengungkapkan Tingkat senioritas auditor berpengaruh terhadap pertimbangan audit auditor.

Seorang auditor professional harus mempunyai pengalaman yang cukup tentang tugas dan tanggung jawabnya. Pengalaman menjadi indikator sangat penting bagi kualifikasi profesional auditor. Auditor yang tidak berpengalaman akan melakukan kesalahan lebih besar dibandingkan dengan auditor yang berpengalaman. Ariyantini (2014) mengatakan bahwa pengalaman auditor berpengaruh terhadap audit judgment.Hasil Penelitian Vincent dan Osesoga (2019) berbeda bahwa pengalaman auditor tidak berpengaruh terhadap audit judgment. Selain pengalaman auditor, keahlian audit juga juga mempengaruhi auditor untuk mengambil keputusan dalam suatu penilain atau judgment. Keahlian audit menurut Artha, et al. (2014) adalah kemampuan dan pengetahuan auditor akan dunia audit itu sendiri yang berasal dari pendidikan formalnya dan ditunjang dengan pengalaman dalam praktik audit. Mengingat peran audit dalam menentukan Judgment diperlukan sikap Profesional yang didasarkan pada pengalaman dan keahlian auditor yang diberikan. Dengan demikian, semakin tinggi keahlian auditor, maka audit judgement yang dihasilkan menjadi semakin tepat. Hasil penelitian Drupadi dan Sudana (2015) menyatakan bahwa keahlian auditor berpengaruh signifikan terhadap audit judgement sedangkan Puspitasari (2018) hasil penelitiannya menunjukkan bahwa keahlian auditor tidak berpengaruh terhadap audit judgment.

Faktor Senioritas auditor, Pengalaman auditor dan keahlian auditor dapat mempengaruhi audit judgment yang dapat diperkuat atau diperlemah dengan adanya variabel moderasi. Variabel moderasi dalam penelitian ini menggunakan locus of control. Locus of control menurut Sari dan Ruhiyat (2017) adalah persepsi seorang individu atas suatu kejadian, dapat atau tidak seorang individu tersebut mengendalikan kejadian yang terjadi itu. Seorang auditor yang memiliki locus of control yang terkendali dapat mengendalikan stress dan lingkungan tempat kerja yang berat dengan pengendalian diri, maka akan mempengaruhi audit judgement yang dibuat. Berdasarkan teori dan fenomena serta research gap yang diungkapkan diatas maka dilakukan penelitian ini mengenai pengaruh senioritas auditor, pengalaman, keahlian auditor, terhadap profesionali judgment dengan locus of control sebagai variabel pemoderasi di kantor akuntan publik wilayah dki jakarta.

Tujuan Penelitian ini yang ingin dicapai adalah pengaruh senioritas auditor, pengalaman auditor, keahlian auditor, terhadap profesional judgment dengan locus of control sebagai variabel pemoderasi.

\section{METODE \\ Jenis Penelitian}

Jenis penelitian yang digunakan adalah penelitian kuantitatif dengan bentuk penelitian survey, Pengumpulan data menggunakan analisis data yang bersifat kuantitatif/statistik dengan tujuan untuk menguji hipotesis yang telah ditetapkan.

\section{Populasi Dan Sampel}

Sasaran populasi dalam penelitian ini adalah kantor akuntan publik di Dki jakarta. Data kantor akuntan publik di ambil dari website Ikatan Akuntan Publik Indonesia (IAPI) dan directori nya. Sampel penelitian ini pada Table 1 merupakan auditor yang terdaftar di kantor akuntan public Dki Jakarta. Teknik pengembalian sampel pada penelitian ini menggunakan probability sampling dengan simple random sampling. Adapun kriteria yang digunakan dalam penelitian ini adalah :

1. Junior auditor, Senior auditor, supervisor, manager partner yang sudah lama bekerja pada kantor akuntan publik.

2. Telah menduduki jabatan dan lama bekerja minimal 1 tahun

3. Terlibat langsung dalam pengauditan

[Table 1 about here.] 


\section{Metode Analisis Data}

Menggunakan WarpPLS (Partial Least Square)

Versi 7.0. diantaranya Merancang Inner Model, Merancang Model Pengukuran (outer model), Mengkonstruksi Diagram Jalur, Konversi Diagram Jalur ke Sistem Persamaan, Estimasi: outer model dan inner model, Evaluasi Goodness of Fit, dan Pengujian Hipotesis (Resampling Bootstraping).

\section{HASIL DAN PEMBAHASAN}

\section{Deskripsi Data dan/atau Gambaran Umum Penelitian}

Penyebaran kuisioner dalam penelitian ini adalah 150 auditor di KAP DKI Jakarta. Dari keseluruhan kuesioner yang disebar, kembali sebanyak 100\% kemudian data dapat diolah (diuji dan dianalisis) sebanyak 150 kuisioner.

\section{Analisis Deskriptif Responden}

Pada bagian berikut mendeskripsikan data-data yang diperoleh dari responden. Data deskriptif menggambarkan keadaan atau kondisi responden yang perlu diperhatikan sebagai tambahan informasi untuk memahami hasil penelitian.

[Table 2 about here.]

Berdasarkan Table 2 responden lebih didominasi oleh Auditor Pria dibandingkan auditor wanita. Dari 150 responden, sebanyak 95 orang atau $63 \%$ berjenis kelamin laki-laki sedangkan 55 orang atau $37 \%$ berjenis kelamin perempuan. Berdasarkan Table 3 Dari segi usia, rata-rata responden memiliki usia diatas 26 tahun baik responden lakilaki maupun perempuan. Pertimbangan menggunakan usia responden sebagai data pendukung dalam penelitian ini didasari pada asumsi bahwa usia seseorang berpengaruh terhadap tindakan dan perilakunya. Semakin matang usia seseorang semakin matang dalam berpikir dan berperilaku. Dengan demikian setiap tindakan yang dilakukan tentu sudah difikirkan sebelumnya. Dalam penelitin ini kematangan berpikir diperlukan untuk memberikan jawaban yang rasional terkait pertayaan penelitian.

[Table 3 about here.]

Berdasarkan Table 4 Berdasarkan tingkat pendidikan dan masa kerja, responden laki-laki maupun perempuan rata-rata memiliki tingkat pendidikan sarjana dengan masa kerjanya diatas satu tahun. Tingkat pendidikan dapat mempengaruhi perilaku seseorang. Semakin tinggi tingkat pendidikan seseorang maka ucapan, perbuatan dan pemikiran semakin matang. Dalam penelitian ini untuk menjaring persepsi auditor atas fenomena yang diteliti, diperlukan kematangan berpikir dan menganalisis tingkat pertayaan yang diajukan untuk memperoleh jawaban yang rasional. Hal inilah yang menjadi argumentasi peneliti untuk menjaring data responden melalui tingkat pendidikan.

[Table 4 about here.]
Berdasarkan Table 5 bahwa jumlah responden dalam penelitian ini berjumlah 150 orang yang memiliki jabatan sebagai Patner, Manager auditor, Senior auditor dan junior auditor. Patner berjumlah 15 orang (10\%), manager auditor berjumlah 26 orang (17\%), senior auditor berjumlah 41 orang (27\%) dan junior auditor berjumlah 68 orang $(46 \%)$.

\section{[Table 5 about here.]}

\section{Analisis Data}

\section{Uji Outer Model}

Pengujian outer model dilakukan dengan 3 kriteria yaitu, validitas konvergen, validitas diskriminan dan reliabilitas.

\section{Validitas Konvergen}

Validitas konvergen bertujuan untuk mengkonfirmasi pengukuran konstruk. Solimun dkk (2017: 115) memberikan rule of thumb muatan faktor yang dipandang bermakna jika lebih besar sama dengan 0.30. Dan jika muatan faktor dapat dikatakan signifikan apabila $p$-value lebih kecil dari $\mathrm{P}<$ 0.001 .

\section{Validitas Diskriminan}

Berikut hasil pengujian validitas diskriminan yang diperoleh: Table 6 hasil pengujian validitas diskriminan diatas dapat di jelaskan bahwa untuk hasil variabel Senioritas Auditor (X1) memiliki akar AVE 1.000; korelasinya dengan variabel lain yaitu $0.305,0.235$, dan 0.052 sehingga variabel X1 memenuhi validitas diskriminan. Variabel Pengalaman (X2) memiliki akar AVE 1.000; korelasinya dengan variabel lain yaitu 0.354 dan 0.374 sehingga variabel X2 memenuhi validitas diskriminan. Variabel Keahlian auditor (X3) memiliki akar AVE 1.000; korelasinya dengan variabel lain yaitu 0.492 sehingga variabel $\mathrm{X} 3$ memenuhi validitas diskriminan. Variabel Profesional Judgment (Y) memiliki akar AVE 1.000; tidak memiliki korelasi dengan variabel lain dan variabel $\mathrm{Y}$ ini memenuhi validitas diskriminan.

\section{[Table 6 about here.]}

\section{[Table 7 about here.]}

Berdasarkan Table 7 diatas dapat disimpulkan bahwa masingmasing konstruk composite reliability coefficient untuk variabel $\mathrm{X} 1, \mathrm{X} 2, \mathrm{X} 3$ dan $\mathrm{Y}$ memenuhi standar yang telah ditetapkan yakni $>0.7$ atau dapat dikatakan reliabilitas dapat diterima (cukup baik). Selanjutnya dapat dilihat kembali setiap konstruk cronbach's alpha coefficients untuk variabel $\mathrm{X} 1, \mathrm{X} 2, \mathrm{X} 3$ dan $\mathrm{Y}$ memenuhi standar yang telah ditetapkan yakni $>0.6$ atau dapat dikatakan reliabilitas sedang (cukup).

[Table 8 about here.]

Berdasarkan Table 8 model fit and quality indences pada penelitian ini terdiri dari Average path coefficient (APC) 
dengan hasil penelitian sebesar 0.171 ( $\mathrm{p}=0.024)$ yang artinya baik, karena sesuai dengan kriteria fit. Average $R$ squared (ARS) dengan hasil penelitian $0.380(\mathrm{p}=0.001)$ yang artinya baik, karena sesuai dengan kriteria fit. Average adjusted $R$-square (AARS) dengan hasil penelitian 0.334 ( $\mathrm{p}=$ 0.001 ) yang artinya baik, karena sesuai dengan kriteria fit. Average block VIF (AVIF) dengan hasil penelitian ini sebesar 1.480 yang artinya ideal, karena sesuai dengan kriteria fit. Average full colliearty VIF (AFVIF) dengan hasil penelitian ini sebesar 1.807 yang artinya ideal, karena sesuai dengan kriteria fit. Tenenhaus Gof (GoF) dengan hasil penelitian ini sebesar 0.484 yang artinya ideal, karena sesuai dengan kriteria fit. Sympson's paradox ratio (SPR) dengan hasil penelitian ini sebesar 0.833 yang artinya ideal, karena memenuhi kriteria fit yang ada, yaitu > 0.7. R-squared contribution ratio (RSCR) dengan hasil penelitian sebesar 0.991 yang artinya ideal, karena sesuai dengan kriteria fit. Statistical suppression ratio (SSR) dengan hasil penelitian ini sebesar 1.000 yang artinya ideal, karena sesuai dengan kriteria fit dan yang terakhir nonlinear bivariate causality direction ratio (NLBDR) dengan hasil penelitian ini sebesar 0.583 yang artinya tidak ideal, karena tidak sesuai dengan kriteria fit yang seharusnya Acceptable if $>=0.7$.Maka dapat disimpulkan bahwa hasil analisis penelitian ini 9 dari 10 model memiliki goodness of fit yang baik sesuai dengan kriteria yang telah ditetapkan dan 1 dari 10 model memiliki goodness of fit yang tidak ideal karena kurang memenuhi kriteria fit yang ada. Pada table 4.6 bersifat rule of thumb sehingga selayaknya tidak berlaku secara kaku dan mutlak (Solimun dkk, 2017: 117).

\section{[Table 9 about here.]}

Berdasarkan Table 9 di atas menunjukan bahwa nilai Rsquare variabel professional judgment sebesar 0,38. Nilai Rsquare adjusted sebesar 0,334 memiliki arti bahwa variabilitas konstruk professional judgment yang dapat dijelaskan oleh variabilitas konstruk X1, X2 dan X3 sebesar $38 \%$ sedangkan sisanya $62 \%$ dijelaskan oleh variabel lain di luar yang diteliti.

\section{Uji Hipotesis}

Berikut table pengujian hipotesis yang disajikan dalam

[Table 10 about here.]

Berdasarkan Table 10 diatas terlihat bawa: Senior auditor berpengaruh tidak signifikan terhadap profesional judgment. Hal ini dapat dilihat dari nilai $\mathrm{P}$ values > dari 0.05 (0.389 > 0.05), sehingga hipotesis tidak dibuktikan. Pengalaman berpengaruh signifikan terhadap profesional judgment. Hal ini dapat dilihat dari nilai $\mathrm{P}$ values $<$ dari $0.05(0.001<0.05)$, sehingga hipotesis diterima. Keahlian auditor berpengaruh signifikan terhadap profesional judgment. Hal ini dapat dilihat dari nilai $\mathrm{P}$ values $<$ dari $0.05(0.001<0.05)$, sehingga hipotesis diterima. Locus of control tidak mampu memoderasi pengaruh senior auditor terhadap profesional judgment. Hal ini dapat dilihat dari nilai $\mathrm{P}$ values $>$ dari 0.05
(0.344 > 0.05), sehingga hipotesis tidak dibuktikan.

1) Locus of control tidak mampu memoderasi pengaruh Pengalaman terhadap profesional judgment. Hal ini dapat dilihat dari nilai $\mathrm{P}$ values > dari 0.05 (0.083 > 0.05), sehingga hipotesis tidak dibuktikan.

2) Locus of control tidak mampu memoderasi pengaruh keahlian auditor terhadap profesional judgment. Hal ini dapat dilihat dari nilai $\mathrm{P}$ values $>$ dari $0.05(0.183>0.05)$, sehingga hipotesis tidak dibuktikan.

\section{Pembahasan \\ Pengaruh senioritas auditor terhadap profesional judgment}

Hipotesis pertama dalam penelitian ini adalah senioritas auditor tidak berpengaruh terhadap profesional judgment. Hasil pengujian menunjukkan bahwa hipotesis tidak dapat dibuktikan. Hal ini dapat dilihat pada Table 10. diatas dimana nilai $\mathrm{P}$ Values > dari 0.05 (0.389 > 0.05), sehingga hipotesis ditolak. Nilai koefisien (kolom original sample) sebesar -0.03 artinya memiliki pengaruh negative tidak signifikan yaitu jika senior auditor turun maka profesional judgment juga akan menurun sebesar 0.03. merujuk pada deskripsi data dan hasil penelitian. Factor Pendidikan ikut berperan dalam mempengaruhi senioritas auditor. Respenden dengan berpendidikan sarjana, memiliki kematangan berfikir yang baik untuk bertindak dan berperilaku tertentu. Oleh karena itu, seorang auditor yang sudah lebih pengalaman, dapat mencari informasi atau pengetahuan secara teori untuk mengasah judgment lebih baik lagi.

\section{Pengaruh Pengalaman auditor terhadap profesional judgment}

Ini dibuktikan berdasarkan uji hipotesis pada Table 10. Dimana t hitung sama dengan 0,298 sedangkan $\mathrm{p}$ value sama dengan 0.05. Ini menunjukan bahwa hipotesis diterima. Artinya pengalaman auditor berpengaruh terhadap profesional judgment.

Hal ini berarti bahwa, Auditor yang memiliki pengalaman akan semakin peka dalam memahami setiap informasiinformasi yang relevan sehubungan dengan yang akan diambil. Semakin peka dengan kesalahan penyajian laporan keuangan dan semakin memahami hal-hal terkait dengan kesalahan yang ditemukan tersebut. Auditor yang memiliki pengalaman akan belajar secara langsung dalam memproses informasi yang releven, menganalisis bukti-bukti audit dan menghadapi tugas audit, sehingga dapat mendukung saat memutuskan judgment yang benar untuk menentukan kualitas dari hasil audit dan juga opini yang akan dikeluarkan auditor.

\section{Pengaruh Keahlian auditor terhadap profesional judgment}

Hasil penelitian ini menunjukkan bahwa pengalaman auditor berpengaruh terhadap profesional judgment. Ini dibuktikan berdasarkan uji hipotesis pada Table 10. Dimana t hitung sama dengan 0,298 sedangkan $\mathrm{p}$ value sama dengan 0.05. Ini menunjukan bahwa hipotesis diterima. Artinya pengalaman auditor berpengaruh terhadap profesional 
judgment. Hal ini berarti bahwa auditor yang mempunyai pemahaman dan pengetahuan yang lebih baik. Akan lebih mampu memprediksi kesalahan- kesalahan dalam penyajian laporan keuangan.

Pengaruh Senioritas auditor terhadap profesional judgment dengan locus of control sebagai variabel moderasi

Hasil penelitian ini menemukan bahwa keahlian auditor berpengaruh terhadap profesional judgment. Hal tersebut terlihat dalam Table 10 dimana nilai $\mathrm{P}$ values $<$ dari $0.05(0.001<0.05)$, sehingga hipotesis diterima. Nilai koefisien (kolom original sample) sebesar 0.418 artinya memiliki pengaruh positif, yaitu jika keahlian auditor meningkat maka profesional judgment juga akan meningkat sebesar 0.418. hal tersebut

berarti bahwa dengan senioritas yang tinggi saja tidak cukup memengaruhi audit judgment yang dihasilkan oleh auditor, sehingga diperlukan variabel lain yang dapat memperkuat pengaruhnya terhadap audit judgment, dalam penelitian ini digunakan locus of control sebagai variabel moderasi.

\section{Pengaruh Pengalaman auditor terhadap profesional judgment dengan locus of control sebagai variabel moderasi}

Ningtyas (2016) mengatakan bahwa indikator pengalaman auditor adalah lamanya berkerja sebagai auditor dan banyaknya tugas pemeriksaan. Berdasarkan hasil Locus of control tidak mampu memoderasi pengaruh Pengalaman terhadap profesional judgment. Hal ini dapat dilihat di Table 10. dimana nilai $\mathrm{P}$ Values $>$ dari $0.05(0.083>0.05)$, sehingga hipotesis ditolak. Nilai koefisien (kolom original sample) sebesar 0.142. karena variabel locus of control tidak mampu memoderasi terhadap audit judgement, maka locus of control atau persepsi pribadi tentang karakteristik individu tersebut tidak memperkuat atau memperlemah adanya tekanan yang diterima seorang auditor terhadap judgement yang dibuat

\section{Pengaruh Keahlian auditor terhadap profesional judgment dengan locus of control sebagai variabel moderasi.}

Berdasarkan hasil penelitian bahwa, Locus of control tidak mampu memoderasi pengaruh keahlian auditor terhadap profesional judgment. Hal tersebut sesuai dengan table 4.12. dimana nilai $\mathrm{P}$ - values $>$ dari 0.05 atau $(0.344>$ 0.05 ), sehingga hipotesis ditolak. Nilai koefisien (kolom original sample) sebesar 0.042. hal tersebut karena Variabel locus of control tidak memoderasi pengaruh keahlian auditor terhadap audit judgement. Berdasarkan uraian tersebut maka hipotesis 6 ditolak. Jadi, locus of control yang berasal dari diri individu jauh lebih lemah pengaruhnya dibanding tekanan . Sehingga adanya locus of control tidak memperlemah atau memperkuat hubungan terhadap audit judgement.
Pada penelitian ini dapat diambil kesimpulan yaitu, Pertama, Pada penelitian ini senioritas auditor berpengaruh tidak signifikan terhadap professional judgment dan tidak memperkuat teori kognitif. Kedua, pengalaman auditor berpengaruh signifikan Terhadap Profesional judgment. Dengan demikian, auditor yang berpengalaman dapat menghasilkan judgment yang lebih tepat dibandingkan auditor yang kurang berpengalaman. Ketiga, Keahlian auditor berpengaruh signifikan terhadap Profesional judgment. Keempat, Locus of Control tidak berpengaruh memoderasi Pengaruh Senioritas Auditor tehadap Profesional Judgment. Sehingga judgment dilakukan oleh auditor lebih independen. Maka pada penelitian ini locus of control tidak berhasil memoderasi senioritas auditor berpengaruh terhadap audit judgement. Kelima, Locus of Control tidak berpengaruh memoderasi Pengaruh pengalaman Auditor tehadap Profesional Judgment. Pengalaman yang dimiliki auditor dapat membuat auditor belajar dari kesalahan di masa lalu agar bisa membuat judgment yang lebih baik lagi. Semakin luas pengalaman kerja seseorang, semakin terampil melakukan pekerjaan dan semakin sempurna pola berpikir dan sikap dalam bertindak untuk mencapai tujuan yang telah ditetapkan. Hasil pada penelitian ini tidak memperkuat dari penelitian terdahulu yang dilakukan oleh Ariyantini dkk. Keenam, Locus of Control tidak berpengaruh memoderasi Pengaruh keahlian Auditor tehadap Profesional Judgment. Pada penelitian ini locus of control tidak mampu memperkuat dari keahlian seorang auditor untuk menjadi seorang auditor yang professional sehingga kurang menguatkan hasil penelitian dari Asih (2006). Implikasi pada penelitian ini dari asspek teoritis mengkonfirmasi dan memperkuat teori Cognitive dimana faktor sentral perilaku individu adalah pengalaman, pemahaman dan pengetahuan (Robbins, 2001), Aspek manajerial diharapkan dengan hasil penelitian ini, dapat memberikan kontribusi bagi kantor akuntan public untuk lebih focus pada keahlian dan pengalaman seorang auditor dalam melakukan pekerjaan profesional sebagai akuntan public dalam melakukan audit pada kliennya.

Keterbatasan pada penelitian yang dilakukan pada kantor akuntan publik di DKI Jakarta dengan menggunakan kuesioner. Dikarenakan Pandemi Covid 19, peneliti tidak dapat melakukan wawancara langsung dan mengumpulkan data langsung ke masing-masing perusahaan. Konfirmasi data yang dilakukan oleh peneliti dengan Goegle form.

\section{REFERENCES}

Andryani dkk. 2019. Pengaruh Tekanan Ketaatan, Keahlian Audit Dan Pengalaman audit Terhadap Audit Judgment Dengan Kompleksitas Tugas sebagai Variabel Pemoderasi. Jurnal Riset Akuntansi Aksioma. Vol.18, No, 2. Tahun 2019. Hal 79-114.

Agustini, Ni Ketut Riski dan Ni Ketut Lely Aryani Merkusiwati. 2016. Pengaruh Tekanan Ketaatan, Senioritas Auditor, dan Tekanan Anggaran Waktu Terhadap Audit Judgment. Bali: Universitas Udayana. Jurnal Auntansi Vol.15, No:1, Hal 433-462.

Ariyantini, Kadek Evi, dkk. 2014. Pengaruh Pengalaman 
Auditor, Tekanan Ketaatan Dan Kompleksitas Tugas Terhadap Audit Judgment, Bali. EJurnal Akuntansi Universitas Pendidikan Ganesha Vol 2. No 1 Tahun 2016. Hal 1-10.

Ayundia. 2015. Pengaruh Tekanan Ketaatan Pengetahuan dan Pengalaman auditor terhadap audit judgment Dengan Kompleksitas Tugas Sebagai Variabel Moderasi. Pekanbaru. Universitas Riau. Jurnal Fekon.Vol 2,No 2.Tahun 2015. Hal 1-15.

Artha, I Made Angga Prma, et al. 2014. Pengaruh Keahlian Audit, Konflik Peran, Dan Kompleksitas Tugas Terhadap Audit Judgment, Singaraja. Universitas Pendidikan Ganesha. Jurnal Vol 2. No 1 Tahun 2014. Hal-12.

Aeni, Ida Nur. 2015. Pengaruh Akuntabilitas Dan Self Review Terhadap Debiasing Audit Judgment Mengenai Laporan Audit Dan Going Concern Dengan Locus Of Control Sebagai Variabel Moderasi. Yogyayakarta. Universitas Yogyakarta.

Alamri et al. 2017. Pengaruh Keahlian, Pengalaman, Kompleksitas Tugas Dan Independensi Terhadap Audit Judgment Audit Internal Pada Inspektorat Provinsi Gorontalo. Jurnal EMBA. Vol 5, No 2, Tahun 2017. Hal 593-601.

Anugrah, Suci Praditaningrum. 2012. Faktor-Faktor Yang Berpengaruh Terhadap Audit Judgment. Skripsi. Universitas DiPonegoro Semarang.

Cahayu, Dwi Ranti. 2013. Pengaruh Etika, Pendidikan, Dan Pengalaman Terhadap

Fitriana, Rahayu. 2014. Pengaruh Kompleksitas Tugas, Tekanan Ketaatan, Tingkat Senioritas Auditor, Keahlian Auditor, Dan Hubungan Dengan Klien Terhadap Audit Judgment. JOM FEKON. Vol, 1 No 2. Tahun 2014. Hal 1-17.

Himawan F.A dan Emirila Rara. 2010. Pengaruh Persepsi Auditor Atas Kompetensi, Independensi Dan Kualitas Audit Terhadap Umur Kantor Akuntan Publik Di Jakarta, Jakarta : Institut Bisnis Nusantara. ESENSI Volume 13,No. 3 Tahun 2010. Hal 1-28.

Herliansyah, Yudhi dan Meifida Ilyas. 2006. Pengaruh Pengalaman Auditor Terhadap penggunaan Bukti Tidak Relevan Dalam Auditor Judgment. Jurnal Simposium Nasional Akuntansi IX. Padang.

Intiyas, dkk. 2007. Situasi Akuntan Publik dari Aspek Keperilakuan. The 1 stAccounting Conference. Depok. Universitas Indonesia.

Irianti, Lingga Resvita, 2019. Pengaruh Kompleksitas Tugas, Senioritas Auditor, Dan Tekanan Ketaatan Terhadap Audit Judgment Dengan Locus Of Control Sebagai Pemoderasi, Surabaya : Sekolah Tinggi Ilmu Ekonomi Perbanas.

Irwanto, dkk.2016. Analisis Faktor-Faktor Yang Mempengaruhi Audit Judgment Pada Auditor BPK Ri. Manado: Universitas Sam Ratulangi. Jurnal EMBA Vol.5 No.1 Tahun 2016, Hal. 20 -29.

Komalasari , Rossa dan Erna Hernawati. 2015. Pengaruh
Independensi, Kompleksitas, dan Gender Terhadap Audit Judgment. Jurnal Neo-bis Volume 9, No. 2, Des 2015.

Maharani, Adisti Putri ,2014. Pengaruh Audit Tenure, Audit Fee, Rotasi Audit, dan Spesialisasi Auditor Terhadap Kualitas Audit. Jurnal Kualitas audit-suatu studi dengan pendekatan Earnings Surprise Benchmark. Simposium Nasional Akuntansi.

Prima, Yoga Satria. 2012. Pengaruh Etika Profesi, Independensi, Dan Profesional Judgment Auditor Terhadap Pertimbangan Tingkat Materialitas Dalam Proses Audit Laporan Keuangan ( Studi Empiris Pada Auditor BPK RI Perwakilan Provinsi Sumatera Utara, Banten Dan Jawa Barat). Skripsi. Universitas Sumatra Utara.

Praditaningrum, Anugrah Suci. Dan januarti, Indira. 2012. Analisis Faktor-Faktoryang berpengaruh terhadap Audit judgement. Skripsi. Fakultas Ekonomika dan Bisnis Universitas Diponegoro Semarang.

Pratiwi,Rizki Yuni. 2017. Pengaruh Self Efficacy, Kecerdasan Emosional,Tekanan Ketaatan, Kompleksitas Tugas Dantingkat Senioritas Terhadap audit judgment auditor. JOM Fekon, Vol. 4 No. 1. Tahun 2017. Hal 2765-2779.

Puspita Sari, Desi Eka. 2018. Pengaruh Independensi, Keahlian, Locus Of Control Dan Pengetahuan Mendeteksi Kekeliruan Terhadap Audit Judgement. Program Studi Akuntansi Fakultas Ekonomi Dan Bisnis: Universitas Muhammadiyah Surakarta

Pertiwi, S.E. Dan Gunawan Hendra. 2015. Pengaruh Orientasi Tujuan dan Self-Efficacy Terhadap Audit Judgment. Bandung. Universitas Islam Bandung: Jurnal Penelitian Spesia. Vol 1, No1.Tahun 2015. Hal 1-10.

Pajares, F. 2002. Overview of Social Cognitive Theory and of Self-Efficacy. Emory University: at http://www.emory.edu/EDUCATION/mfp/eff.htm.

Seldivianinggar,Alfrida. 2018. Pengaruh Keahlian, Pengalaman Auditor, Kompleksitas Tugas, dan Tekanan Ketaatan Terhadap Audit Judgment. Surakarta. Universitas Muhammadiyah Surakarta: Jurnal Publikasi Ilmiah.

Sari, Dessy Indah, dan Endang Ruhiyat. 2017. "Locus of Control, Tekanan Ketaatan, dan Kompleksitas Tugas Terhadap Audit Judgement". Jurnal Aset (Akuntansi Riset). Vol: 9, No; 2.

Copyright (c) 2020 and. This is an open-access article distributed under the terms of the Creative Commons Attribution License (CC BY). The use, distribution or reproduction in other forums is permitted, provided the original author(s) and the copy-right owner(s) are credited and that the original publication in this journal is cited, in accordance with accepted academic practice. No use, distribution or reproduction is permitted which does not comply with these terms. 


\section{LIST OF TABLE}

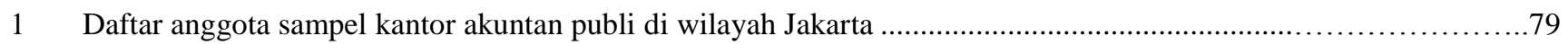

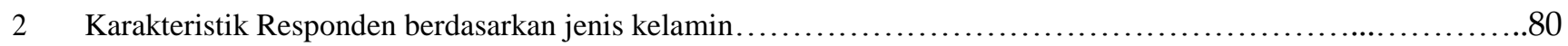

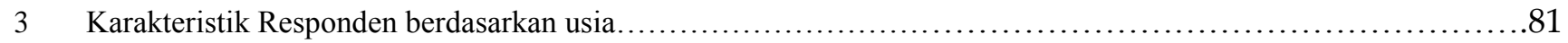

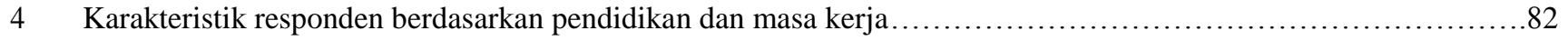

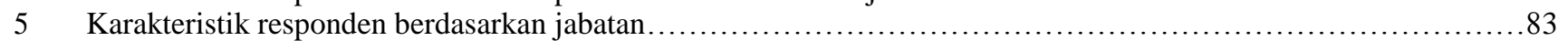

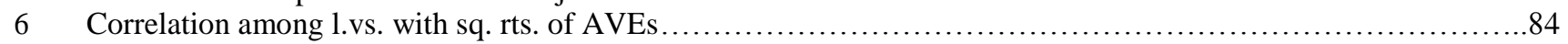

7 Composite Reliability Coefficient and Cronbach's Alpha Coefficient ..............................................

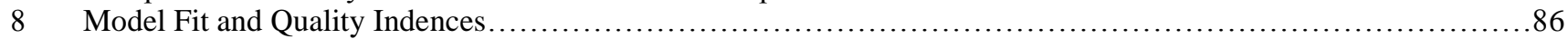

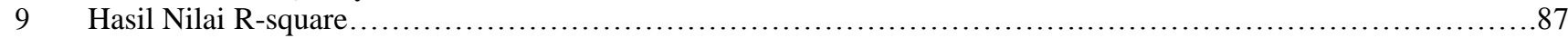

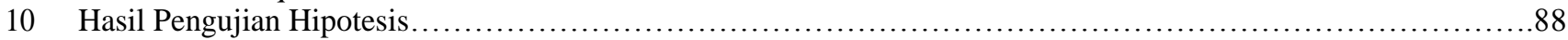


TABLE1/Daftar Anggota Sampel Kantor Akuntan Publik Di Wilayah Jakarta

\begin{tabular}{|c|c|c|}
\hline No & KAP & Alamat \\
\hline 1 & KAP Ishak, Saleh, Soewondo & Bungur Grand Center, Blok B-5, Jl Ciputat Raya No. 4-6 Kebayoran Lama. \\
\hline 2 & KAP Luqman \& Sarifuddin & RT.5/ RW.8, Cilandak Bar,.Kec Cilandak, Kota Jakarta Selatan. \\
\hline 3 & KAP Soejatna Moelyana Dan Rekan & Jl. Batu Mulia M No.83, RT. 6/ RW.7, Meruya Utara, Kembangan, Jakarta Barat. \\
\hline 4 & McMIlan woods & $\begin{array}{l}\text { Jl. TB Simatupang No. 1S, Rt.3/Rw.3,Kuningan, East Cilandak, Pasar Minggu, South } \\
\text { Jakarta City. }\end{array}$ \\
\hline 5 & KAP Aidil Oscar \& Rekan & Jl. Rukan taman Meruya no M78, Kembangan, Jakarta Barat \\
\hline 6 & Kap Rama Wendra & $\begin{array}{l}\text { The Manhattan Square Mid Tower lantai18, Jl. TB Simatupang Kavling 1,S Jakarta } \\
\text { Selatan }\end{array}$ \\
\hline 7 & $\begin{array}{l}\text { KAP Irfan, Abdulrahman Hasan Salipu dan } \\
\text { Dermawan }\end{array}$ & $\begin{array}{l}\text { Jl.Surilang No } 06 \text { A RT.03, RW 01, Kel Gedong, Kec Pasar Rebo, Jakarta Timur, DKI } \\
\text { Jakarta. }\end{array}$ \\
\hline 8 & KAP Jaror \& Rekan & Jalan Ciputat Raya No. 14B, Pondok Pinang Kebayoran Lama, Jakarta Selatan. \\
\hline 9 & KAP Teguh Heru \& Rekan & Jl. Kh Abdullah Syafei No 11, Manggarai Selatan, Tebet Jakarta Selatan \\
\hline 10 & KAP Mennix \& Rekan & $\begin{array}{l}\text { Gedung Menara BTPN Lantai 38, Zona A Jl. Ide Anak Agung Gde Agung Kav 5,5 RT. } \\
\text { 5/R } \\
\text { W.6 Kuningan, East Kuningan, South Jakarta City }\end{array}$ \\
\hline 11 & KAP Krisnawan, Nugroho \& Fahmi & Pasanggarahan office R.102 Jl. Lebak Bulus III No.50 Jakarta Selatan \\
\hline 12 & KAP Ishak Saleh, Soewondo \& Rekan & Jl. HR. Rasuna Said, Kuningan- Jakarta Selatan. \\
\hline 13 & KAP Haryono, Junianto \& Asmoro & $\begin{array}{l}\text { Rukan Sentra Pemuda, No. } 61 \text { kav 18. Jl Pemuda, RT.9 RW.3 Rawamangun, Kec. Pulo } \\
\text { Gadung. Jakarta Timur. }\end{array}$ \\
\hline 14 & KAP Kreston HHES & Jl. Jend Sudirman No.32, Rt.3/RW.2, Karet Tengsin, Kota Jakarta Pusat \\
\hline 15 & Grant Thornton Indonesi & $\begin{array}{l}\text { Jl. Jend Sudirman No. 3, RT 3/RW.4, Karet Semanggi, Kecamatan Setiabudi Kota } \\
\text { Jakarta Selatan. }\end{array}$ \\
\hline 16 & $\begin{array}{l}\text { Kantor Akuntan Publik Heliantono \& } \\
\text { Rekan }\end{array}$ & $\begin{array}{l}\text { JL. Letjen TB Simatupang, Kav 10, Plaza Aminta, Lt } 7 \text { 12310, RT.2/RW.2, Cilandak } \\
\text { Barat, RT.6/RW.14, Pondok Pinang, Kebayoran Lama, Jakarta Selatan } 12430 .\end{array}$ \\
\hline 17 & KAP Ispaiadi Dan Dande & Jl. Pondok Pinang Kebayoran Lama, Jakarta Selatan \\
\hline 18 & KAP Husni, Mucharam \& Rasidi. & Jl. Prof. Dr. Soepomo, SH, No. 178A Jakarta Selatan 12870. \\
\hline 19 & KAP Hertanto Grace Karunawan & $\begin{array}{l}\text { Palma Tower Lt. } 18 \text { Lot F\&G Jl. R.A. Kartini II-S Kav. } 06 \text { Sektor II Pondok Pinang, } \\
\text { Jakarta Selatan, } 12310 .\end{array}$ \\
\hline 20 & KAP Bharata Arifin Mumajad \& Sayuti & $\begin{array}{l}\text { Jalan Rawa Bambu Raya No. } 17 \text { D } \\
\text { RT.013/005, Pasar Minggu, } \\
\text { Jakarta Selatan 12520. }\end{array}$ \\
\hline
\end{tabular}


TABLE2 | Karakteristik Responden berdasarkan jenis kelamin

\begin{tabular}{ll|l|l}
\hline No & Jenis Kelamin & \multicolumn{2}{l}{ Jumlah } \\
\hline 1 & Laki-laki & 95 orang & \\
\hline 2 & Perempuan & 55 orang & $37 \%$ \\
\hline Jumlah & & 150 orang & $100 \%$ \\
\hline
\end{tabular}




\begin{tabular}{|c|c|c|c|c|}
\hline No & Jenis Kelamin & Usia & Jumlah & \\
\hline \multirow[t]{6}{*}{1} & \multirow[t]{6}{*}{ Laki-laki } & 21-25 tahun & 19 orang & $13 \%$ \\
\hline & & 26-31 tahun & 44 orang & $29 \%$ \\
\hline & & 32-37 tahun & 16 orang & $11 \%$ \\
\hline & & 38- 42tahun & 11 orang & $7 \%$ \\
\hline & & 42-48 tahun & 5 orang & $3 \%$ \\
\hline & & 49-54 tahun & 8 orang & $5 \%$ \\
\hline \multirow[t]{7}{*}{2} & \multirow[t]{6}{*}{ Perempuan } & 21-25 tahun & 9 orang & $6 \%$ \\
\hline & & 26-31 tahun & 26 orang & $17 \%$ \\
\hline & & 32-37 tahun & 7 orang & $5 \%$ \\
\hline & & 38-42 tahun & 5 orang & $3 \%$ \\
\hline & & 42-48 tahun & - & $0 \%$ \\
\hline & & 49- 54 tahun & - & $0 \%$ \\
\hline & Jumlah & & 150 orang & \\
\hline
\end{tabular}


TABLE 4 | Karakteristik responden berdasarkan pendidikan dan masa kerja

\begin{tabular}{|c|c|c|c|c|c|}
\hline \multirow{2}{*}{$\begin{array}{l}\text { No } \\
1\end{array}$} & \multirow{2}{*}{$\begin{array}{l}\text { Jenis Kelamin } \\
\text { Laki-laki }\end{array}$} & \multicolumn{2}{|c|}{ Pendidikan } & \multicolumn{2}{|l|}{ Masa Kerja } \\
\hline & & D3 & 9 orang & $<=1$ Tahun & 18 orang \\
\hline & & S1 & 73 orang & 1-5 Tahun & 36 orang \\
\hline & & S2 & 22 orang & 6-10 Tahun & 25 orang \\
\hline & & S3 & 3 orang & $>=10$ Tahun & 17 orang \\
\hline \multirow[t]{5}{*}{2} & Perempuan & D3 & 6 orang & $<=1$ Tahun & 15 orang \\
\hline & & S1 & 37 orang & 1-5 Tahun & 19 orang \\
\hline & & S2 & - & 6-10 Tahun & 16 orang \\
\hline & & S3 & - & $>=10$ Tahun & 4 orang \\
\hline & Jumlah & & 150 orang & & 150 orang \\
\hline
\end{tabular}


TABLE 5 | Karakteristik Responden Berdasarkan Jabatan

\begin{tabular}{l|l|l|l}
\hline No & Jabatan & Jumlah & $\%$ \\
\hline 1 & Partner & 15 orang & $10 \%$ \\
\hline 2 & Manager auditor & 26 orang & $17 \%$ \\
\hline 3 & Senior auditor & 41 orang & $27 \%$ \\
\hline 4 & Junior auditor & 68 orang & $46 \%$ \\
\hline & Jumlah & 150 orang & $100 \%$ \\
\hline
\end{tabular}


TABLE 6 | Correlation among I.vs. with sq. rts. of AVEs

\begin{tabular}{l|l|l|l|l}
\hline Variabel & $\mathrm{X} 1$ & $\mathrm{X} 2$ & $\mathrm{X} 3$ & $\mathrm{Y}$ \\
\hline Senioritas Auditor (X1) & 1.0000 & 0.305 & 0.235 & 0.052 \\
\hline Pengalaman (X2) & 0.305 & 1.0000 & 0.354 & 0.374 \\
\hline Keahlian Auditor (X3) & 0.235 & 0.354 & 1.0000 & 0.492 \\
\hline Profesional Judgment (Y) & 0.052 & 0.374 & 0.492 & 1.0000 \\
\hline
\end{tabular}


TABLE 7 | Composite Reliability Coefficient and Cronbach's Alpha Coefficient

\begin{tabular}{l|l|l|l}
\hline No & Variabel & $\begin{array}{l}\text { Composite Reliability } \\
\text { Coefficient }\end{array}$ & $\begin{array}{l}\text { Cronbach's Alpha } \\
\text { Coefficient }\end{array}$ \\
\hline 1. & Senioritas Auditor (X1) & 1.000 & 1.000 \\
\hline 2. & Pengalaman (X2) & 1.000 & 1.000 \\
\hline 3. & Keahlian Auditor (X3) & 1.000 & 1.000 \\
\hline 4. & $\begin{array}{l}\text { Profesional Judgment } \\
(\mathrm{Y})\end{array}$ & 1.000 & 1.000 \\
\hline
\end{tabular}


TABLE 8 | Model Fit and Quality Indences

\begin{tabular}{|c|c|c|c|c|}
\hline No. & $\begin{array}{l}\text { Model Fit and Quality } \\
\text { Indences }\end{array}$ & Kriteria Fit & Hasil Analisis & Keterangan \\
\hline 1 & $\begin{array}{c}\text { Average path coefficient } \\
\text { (APC) }\end{array}$ & $\mathrm{p}<0.05$ & $\begin{array}{c}0.171 \\
(\mathrm{p}=0.024)\end{array}$ & Baik \\
\hline 2 & $\begin{array}{c}\text { Average } R \text {-squared } \\
\text { (ARS) }\end{array}$ & $\mathrm{p}<0.05$ & $\begin{array}{c}0.380 \\
(\mathrm{p}<0.001)\end{array}$ & Baik \\
\hline 3 & $\begin{array}{l}\text { Average adjusted } R \text { - } \\
\text { square (AARS) }\end{array}$ & $\mathrm{p}<0.05$ & $\begin{array}{c}0.334 \\
(p=0.001)\end{array}$ & Baik \\
\hline 4 & $\begin{array}{c}\text { Average block VIF } \\
\text { (AVIF) }\end{array}$ & $\begin{array}{c}\text { Acceptable if }<=5, \\
\text { ideally }<=3.3\end{array}$ & 1.480 & Ideal \\
\hline 5 & $\begin{array}{c}\text { Average full colliearty } \\
\text { VIF (AFVIF) }\end{array}$ & $\begin{array}{c}\text { Acceptable if }<=5, \\
\text { ideally }<=3.3\end{array}$ & 1.807 & Ideal \\
\hline 6 & Tenenhaus Gof (GoF) & 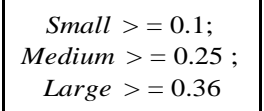 & 0.484 & Ideal \\
\hline 7 & $\begin{array}{c}\text { Sympson's paradox ratio } \\
\text { (SPR) }\end{array}$ & $\begin{array}{c}\text { Acceptable if }>= \\
0.7, \text { ideally } 1\end{array}$ & 0.833 & ideal \\
\hline 8 & $\begin{array}{c}\mathrm{R}-\text { squared contribution } \\
\text { ratio }(\mathrm{RSCR})\end{array}$ & $\begin{array}{c}\text { Acceptable if }>= \\
0.9, \text { ideally } 1\end{array}$ & 0.991 & ideal \\
\hline 9 & $\begin{array}{c}\text { Statistical suppression } \\
\text { ratio }(\mathrm{SSR})\end{array}$ & $\begin{array}{c}\text { Acceptable if }>= \\
0.7\end{array}$ & 1 & Ideal \\
\hline 10 & $\begin{array}{c}\text { Nonlinear bivariate } \\
\text { causality direction ratio } \\
\text { (NLBDR) }\end{array}$ & $\begin{array}{c}\text { Acceptable if }>= \\
0.7\end{array}$ & 0.583 & Tidak Ideal \\
\hline
\end{tabular}


TABLE 9| Model Fit and Quality Indences

\begin{tabular}{|l|l|l|l|l|l|l|l|}
\hline $\mathrm{t}$ & PA & KA & LC_M & PJ_Y & LC_M*SA & LC_M*PA & LC_M*KA \\
\hline & & & & 0.38 & & & \\
\hline
\end{tabular}




\begin{tabular}{|c|c|c|c|c|c|c|}
\hline \multirow[t]{2}{*}{ No. } & \multicolumn{3}{|c|}{$\begin{array}{c}\text { Hubungan Antar Variabel (Variabel Penjelas } \\
\text { Terhadap Variabel Respon) }\end{array}$} & \multirow{2}{*}{ Koefisien Path } & \multirow{2}{*}{ P-value } & \multirow{2}{*}{ Keterangan } \\
\hline & Variabel Penjelas & $\begin{array}{l}\text { Variabel } \\
\text { Moderasi }\end{array}$ & $\begin{array}{c}\text { Variabel } \\
\text { Respon }\end{array}$ & & & \\
\hline 1 & $\mathrm{X} 1$ & & Y & -0.03 & $\mathrm{P}=0.389$ & Weakly Significant \\
\hline 2 & $\mathrm{X} 2$ & & $\mathrm{Y}$ & 0.298 & 0.001 & Significant \\
\hline 3 & $\mathrm{X} 3$ & & Y & 0.418 & $<0.001$ & Significant \\
\hline 4 & $\mathrm{X} 1$ & LC_M*SA & Y & 0.042 & 0.344 & Unable to moderate \\
\hline 5 & $\mathrm{X} 2$ & LC_M*PA & $Y$ & 0.142 & 0.083 & Unable to moderate \\
\hline 6 & X3 & LC_M*KA & $\mathrm{Y}$ & -0.094 & 0.183 & Unable to moderate \\
\hline
\end{tabular}

